\title{
ANALISIS SEKTOR BASIS DAN NON BASIS DI KABUPATEN BOLAANG MONGONDOW TIMUR
}

\author{
Alen Gifthovel Sumayow \\ Paulus A. Pangemanan \\ Ellen G. Tangkere
}

\begin{abstract}
This study aims to determine what sectors are the base and non-base sectors in East Bolaang Mongondow Regency. This study was conducted for three months starting from August to November 2017 in East Bolaang Mongondow Regency. The data used in this study is secondary data obtained from the Central Bureau of Statistics (BPS) Kotamobagu City. The data is in though using descriptive analysis research method. The research result showed that the sectors that are the base sector in East Bolaang Mongondow Regency are Electricity and Gas Procurement, Construction, Information and Communication, and Other Services sectors. "*nkd*.
\end{abstract}

Keywords: basic sectors, and non-base sector, East Bolaang Mongondow Regency

\begin{abstract}
ABSTRAK
Penelitian ini bertujuan untuk mengetahui sektor apa saja yang menjadi sektor basis dan non basis di Kabupaten Bolaang Mongondow Timur. Penelitian ini dilakuakan selama tiga bulan mulai pada bulan Agustus sampai November 2017 di Kabupaten Bolaang Mongondow Timur. Data yang digunakan dalam penelitian ini adalah data sekunder yang di peroleh dari Badan Pusat Statistik (BPS) Kota Kotamobagu. Data tersebut di olah menggunakan metode penelitian analisis deskriptif. Hasil penelitian menunjukkan sektor yang menjadi sektor basis di Kabupaten Bolaang Mongondow Timur adalah sektor Pengadaan Listrik dan Gas, Konstruksi, Informasi dan Komunikasi, dan Jasa lainnya. *jnkd*.
\end{abstract}

Kata kunci: sektor basis, sektor non basis, Kabupaten Bolaang Mongondow Timur

\section{PENDAHULUAN}

\section{Latar Belakang}

Pembangunan ekonomi erat kaitannya dengan pertumbuhan ekonomi. Pembangunan ekonomi mendorong pertumbuhan ekonomi, dan sebaliknya, pertumbuhan ekonomi memperlancar proses pembangunan ekonomi. Sehingga. Pembangunan dipandang sebagai proses multidimensional yang mencakup berbagai perubahan mendasar atas struktur sosial, sikapsikap masyarakat dan institusi-institusi nasional, disamping tetap mengejar akselerasi pertumbuhan ekonomi, serta pengentasan kemiskinan.
Pembangunan daerah menjadi bagian integral dari pembangunan nasional yang diarahkan untuk mengembangkan dan menyeimbangkan laju pertumbuhan antar daerah, antar desa, antar sektor serta pembukaan dan percepatan pembangunan yang akan disesuaikan dengan prioritas dan potensi daerah bersangkutan yang diwujudkan didalam pola pembangunan. Dari segi perencanaan pembangunan pada dasarnya ada 3 (tiga) aspek yaitu: (1) aspek makro; (2) aspek sektoral; (3) aspek regional. Ketiga aspek tersebut saling berkaitan satu sama lainnya sehingga perlu dipadukan dengan sebaik-baiknya agar mencapai hasil optimal (Sadono Sukirno). 
Otonomi daerah merupakan salah satu upaya yang dilakukan untuk mengefektifkan pembangunan daerah. Otonomi daerah memberikan output daerah - daerah otonom yang mampu berkembang menyesuaikan kondisi yang dimiliki. Undang - Undang No. 32 Tahun 2004 tentang Pemerintah Daerah dan Undang - Undang No. 23 Tahun 2004 tentang Perimbangan Keuangan antara Pemerintah Pusat dan Daerah adalah bentuk dukungan dari pemerintah terhadap perkembangan pembangunan perekonomian daerah. Undang-Undang tersebut merupakan landasan bagi daerah untuk membangun daerahnya secara mandiri dengan lebih mengandalkan potensi yang dimiliki daerah. Undang-Undang ini juga memberikan peranan yang lebih luas kepada pemerintah daerah untuk merancang pembangunan daerah yang sesuai dengan keinginan masyarakat sekitar. Pentingnya peningkatan perekonomian suatu daerah, di dalam meningkatkan kesejahteraan bagi penduduk. Oleh karena itu suatu daerah perlu mengetahui sektor apa yang menjadi sektor basis di wilayah tersebut. Dengan mengetahui sektor basis, dapat diketahui sektor apa yang menjadi penompang wilayah tersebut. Demikian pula dengan kabupaten Bolaang mongondow Timur dalam mendorong pertumbuhan ekonominya maka perlu mengidentifikasi sektor-sektor mana yang dapat di unggulkan dan dapat memberikan hasil yang baik, sehingga diharapkan dapat menopang sektor-sektor lainnya yang belum berkembang.

Kabupaten Bolaang Mongondow Timur adalah kabupaten yang baru dimekarkan pada tahun 2008, kabupaten ini dibentuk berdasarkan Undang-Undang Nomor 29 tahun 2008. Walaupun Kabupaten Bolaang Mongondow Timur tergolong baru kabupaten ini adalah salah satu Kabupaten di Provinsi Sulawesi Utara yang memiliki banyak kemajuan dalam segi perekonomian yang dicerminkan dalam angka pendapatan Domestik Regional Bruto (PDRB) dan pertumbuhan ekonomi dari tahun ke tahun. Potensi ekonomi diantaranya pertambangan, pertanian, jasa, dan pariwisata.

\section{Rumusan Masalah}

Sektor-sektor apakah yang menjadi sektor basis dan non basis dalam perekonomian Kabupaten Bolaang Mongondow Timur 20112015.

\section{Tujuan Penelitian}

Berdasarkan latar belakang dan perumusan masalah maka tujuan yang akan dicapai dari penelitian ini adalah, untuk mengetahui sektor basis dan non basis dalam perekonomian wilayah Kabupaten Bolaang Mongondow Timur 20112015.

\section{Manfaat Penelitian}

Manfaat penelitian ini yaitu sebagai tambahan informasi dan bahan kajian tentang gambaran/informasi tentang potensi pertumbuhan di Kabupaten Bolaang Mongondow Timur sehingga pemerintah daerah dapat lebih mengembangkan potensi daerahnya. Serta dapat menjadi masukan bagi para pembuat kebijakan yang berhubungan dengan pembangunan Kabupaten Bolaang Mongondow Timur dalam rangka program pembangunan selanjutnya dan tetap mempertahankan pertumbuhan ekonomi yang ada.

\section{METODE PENELITIAN}

\section{Lokasi dan Waktu Penelitian}

Penelitian ini dilaksanakan di Kabupaten Bolaang Mongondow Timur yang merupakan salah satu dari 15 Kabupaten/Kota di Provinsi Sulawesi Utara dan waktu penelitian ini dilaksanakan dari bulan Agustus sampai bulan November 2017.

\section{Metode Pengumpulan Data}

Data yang digunakan dalam penelitian ini adalah jenis data sekunder, yaitu data PDRB sektor-sektor ekonomi menurut lapangan usaha di Kabupaten Bolaang Mongondow Timur dari tahun 2011-2015 dan data PDRB sektor-sektor ekonomi menurut lapangan usaha di Provinsi Sulawesi Utara periode 2011-2015. Data ini diperoleh dari BPS (Badan Pusat Statistik), berbagai literatur serta situs resmi Kabupaten Bolaang Mongondow Timur dan Provinsi Sulawesi Utara, serta sumber lainnya yang relevan. 


\section{Konsep Pengukuran Variabel}

Variabel yang diukur dalam penelitian ini adalah sebagai berikut:

1. Nilai PDRB Provinsi Sulawesi Utara Tahum 2011 sampai tahun 2015 atas dasar harga konstan.

2. Nilai PDRB Kabupaten Bolaang Mongondow Timur tahun 2011 sampai tahun 2015 atas dasar harga konstan.

\section{Metode Analisis Data}

1. Analisis Location Quotient (LQ)

Analisis identifikasi sektor usaha utama Di Kab.BOLTIM menggunakan analisis Location Quotient (LQ) yaitu dengan membandingkan antara pangsa relatif pendapatan sektor i pada tingkat wilayah terhadap pendapatan total wilayah dengan pangsa relatif pendapatan sektor i pada tingkat nasional terhadap pendapatan total nasional.

Rumus LQ yang digunakan adalah:

$$
L Q=\frac{\mathrm{Si} / \mathrm{s}}{\mathrm{Ni} / \mathrm{N}}
$$

Kerangan:

$$
\begin{array}{ll}
\mathrm{LQ} & =\text { Indeks Location Quotient } \\
\mathrm{Si} & =\text { PDRB sektor i Kab.Boltim } \\
\mathrm{S} & =\text { PDRB total Kab.Boltim } \\
\mathrm{Ni} & =\text { PDRB sektor i di Provinsi } \\
& \quad \text { Sulawesi Utara } \\
\mathrm{N} & =\text { PDRB total Sulawesi Utara. }
\end{array}
$$

Dalam persamaan di atas, maka ada tiga kemungkinan nilai LQ yang akan diperoleh yaitu:

1. Nilai $L Q=1$. ini berarti bahwa tingkat spesialisasi sektor i di Kabupaten BOLTIM adalah sama dengan sektor yang sama dalam perekonomian Provinsi Sulawesi Utara

2. Nilai $L Q>1$. ini berarti bahwa tingkat spesialisasi sektor i di Kabupaten BOLTIM lebih besar dibandingkan dengan sektor yang sama dalam perekonomian Sulawesi Utara.
3. Nilai LQ $<1$. Ini berarti bahwa tingkat spesialisasi sektor i di Kabupaten BOLTIM lebih kecil dibandingkan sektor yang sama dalam perekonomian Provinsi Sulawesi Utara.

Dengan kata lain apabila LQ > 1, maka dapat disimpulkan bahwa sektor tersebut merupakan sektor basis dan potensial untuk dikembangkan sebagai penggerak perekonomian Kabupaten BOLTIM. Sebaliknya apabila nilai LQ $<1$, maka sektor tersebut bukan merupakan sektor basis dan kurang potensial untuk dikembangkan sebagai penggerak perekonomian Kabupaten BOLTIM.

2. Analisis Dinamic Location Quotien

Analisis Dinamic Location Quotient (DLQ) Sebagai alternatif untuk melengkapi kelemahan dari analisis LQ maka digunakan analisis DLQ. Metode ini digunakan untuk mengetahui peranan sektor prioritas. Karena dapat memberikan hasil yang lebih tepat dengan mengacu pada laju pertumbuhan sektor ekonomi.

Rumus DLQ yang digunakan adalah:

$$
D L Q=\left(\frac{(1+G i n) /(1+G n)}{(1+G i) /(1+G)}\right)^{t}
$$

Keterangan:

DLQ = Indeks dari laju pertumbuhan sector (i) di Kabupaten Boltim

Gin = Rata-rata laju pertumbuhan (PDRB) sektor ekonomi (i) di Kabupaten Boltim

$\mathrm{Gi}=$ Rata-rata laju pertumbuhan (PDRB) sektor ekonomi (i) di Provinsi Sulawesi Utara

Gn = Rata-rata laju pertumbuhan (PDRB) di Kabupaten Boltim

$\mathrm{G}$ = Rata-rata laju pertumbuhan (PDRB) di Provinsi Sulawesi Utara

$\mathrm{t}=$ Jangka waktu pertumbuhan DLQ

Kriteria yang digunakan adalah: 
a. Apabila DLQ suatu sektor > 1, maka laju pertumbuhan sektor (i) terhadap pertumbuhan PDRB daerah (n) lebih cepat dibandingkan dengan proporsi laju pertumbuhan sektor tersebut terhadap PDRB daerah himpunannya. Masa depan keadaan masih tetap sehingga sebagaimana adanya saat ini, maka dapat diharapkan bahwa sektor ini akan unggul dalam persaingan;

b. Apabila DLQ suatu sektor < 1, maka laju pertumbuhan sektor (i) terhadap pertumbuhan PDRB daerah (n) lebih lambat dibandingkan dengan proporsi laju pertumbuhan sektor tersebut terhadap PDRB daerah himpunannya. Kondisi demikian maka kedepannya sektor ini akan kalah bersaing dengan sektor yang sama di daerah lain dalam daerah himpunannya;

c. Sedangkan apabila DLQ suatu sektor $=1$, maka sektor proporsi laju pertumbuhan sektor (i) terhadap pertumbuhan PDRB daerah (n) sebanding dengan proporsi laju pertumbuhan sektor tersebut dengan laju pertumbuhan PDRB daerah himpunan.

\section{HASIL DAN PEMBAHASAN}

\section{Gambaran Umum \\ Kabupaten Bolaang Mongondow Timur}

\section{Letak dan Luas Wilayah}

Kabupaten Bolaang Mongondow Timur terletak dibagian Selatan provinsi Sulawesi Utara atau diantara 0: 23' 25' ' LU - 124: 19' 39' BT dan 0: 57' 33' LU - 124: 45' 38', BT.

Batas Wilayah Kabupaten Bolaang Mongondow Timur :

Bagian Utara :

Kabupaten Minahasa Selatan, Kabupaten Minahasa Tenggara dan Kabupaten Bolaang Mongondow Bagian Selatan : Laut Maluku
Bagian Barat :

Kota Kotamobagu, Kabupaten Bolaang Mongondow dan Kabupaten Bolaang Mongondow Selatan

Bagian Timur :

Kabupaten Minahasa Tenggara dan Laut Maluku

Luas Wilayah :

$\pm 910,176 \mathrm{~km}^{2}$ atau sekitar 5,95\% dari luas wilayah Provinsi Sulawesi Utara.

Panjang garis pantai:

$\pm 122,878 \mathrm{~km}$ dengan karakteristik sebagian besar adalah pantai berpasir membentang dari teluk Buyat hingga teluk Jikobelanga dan pulau Lampu.Panjang pantai tiap kecamatan menurut pengukuran Citra Satelit (2012) yaitu: kecamatan Kotabunan ( \pm $25,51 \mathrm{~km})$, kecamatan Tutuyan $( \pm 27,016$ $\mathrm{km})$, kecamatan Nuangan $( \pm 70,35 \mathrm{~km})$. Luas wilayah laut 4 mil: $466,02 \mathrm{~km}^{2}$.

\section{Topografi}

Sebagian besar wilayah kabupaten Bolaang Mongondow Timur merupakan wilayah relatif datar (kelerengan 0-8 \%) dengan luas 12.745,06 hektar atau $14 \%$, landai (kelerengan 8-15 \%) dengan luas 4.496,08 atau 4,94 \%, agak curam (kelerengan 15-25 \%) dengan luas 14.011,65 Hektar atau 15,39 \%. dan wilayah curam dengan kelerengan $25 \%-40 \%$ adalah 37.021,03 hektar atau 40,67\%, sedangkan sangat curam dengan kelas lereng > $40 \%$ seluas $22.743,77$ hektar atau $24,99 \%$. Untuk ketinggian wilayah bervariasi di tiap kecamatan, ketinggian 0-175 m dpl terdapat: Kecamatan Kotabunan, Tutuyan, dan Nuangan. Sedangkan ketinggian 175-1.750 m dpl terdapat di kecamatan Kotabunan, Tutuyan, dan Nuangan, Modayag dan Modayag Barat. Dilihat dari tekstur tanahnya, maka sebagian besar daerah kabupaten Bolaang Mongondow Timur terdiri dari tanah. Dystropepts, Dystrandepts, Tropaquepts, Humitropepts, Tropudalfs, Tropohumults, Tropudults, Troporthents, Eutropepts, Hydrandepts, Rendolls, Sulfaquents, Hydraquents, Fluvaquentd, Tropohemists, Tropopsamments. 


\section{Keadaan Iklim}

Kabupaten Bolaang Mongondow Timur secara umum beriklim tropis dengan suhu berkisar $28^{\circ} \mathrm{C}-30^{\circ} \mathrm{C}$ dengan suhu rata-rata pertahun $29^{\circ} \mathrm{C}$. Suhu terendah terjadi pada bulan November dan Desember sedangkan tertinggi pada bulan Juni dan Juli. Curah hujan dipengaruhi oleh keadaan iklim, keadaan topografi dan perputaran/pertemuan arus udara. Jumlah curah hujan cukup tinggi, mencapai 2000-3000mm. Berdasarkan zona agroklimat, daerah ini tergolong dalam zona B1, B2 dan C2. Menurut klasifikasi Smith-Ferguson, tipe iklim di wilayah Utara kabupaten ini adalah tipe B dengan curah hujan rata-rata $1200-1350 \mathrm{~mm} / \mathrm{tahun}$ (120 hari hujan), daerah basah dengan vegetasi hutan hujan tropik. Sedangkan menurut Koppen, termasuk tipe Bf yaitu hujan tropik dengan ciri-ciri selalu basah, hujan $60 \mathrm{~mm} / \mathrm{bulan}$.

\section{Lingkungan Hidup}

Dampak kegiatan manusia dan gejala alam mempengaruhi kondisi lingkungan hidup di kabupaten Bolaang Mongondow Timur. Dampak tersebut dapat mengganggu kualitas dan kelestarian lingkungan hidup. Adanya aktifitas pertambangan, kebakaran hutan, indikasi pencemaran air, gangguan Daerah Aliran Sungai (DAS), pembalakkan liar, konversi lahan dapat mengancam keseimbangan ekosistem secara luas yang dapat menyebabkan kerusakan lingkungan hidup. Dalam wilayah kabupaten Bolaang Mongondow Timur terdapat 7 (tujuh) Daerah Aliran Sungai (DAS) dengan luas hamparan mencapai $910.017,6$ ha, yang terdiri dari DAS Buyat - Kotabunan (73.955,34 ha), DAS Lembean - Likupang (97,54 ha), DAS Molibagu Pinolosian (122,95 ha), DAS Ongkag - Dumoga (11.153,52 ha), DAS Poigar - Tenga (5.586,91 ha), yang meliputi sungai, DAS Ranoyapo (101,32 ha), serta DAS Tondano (0,02 ha).

\section{Keadaan Penduduk}

Jumlah penduduk Kabupaten Bolaang Mongondow Timur sebanyak 63654 jiwa yang mencakup mereka yang bertempat tinggal di daerah perkotaan sebanyak 5623 jiwa atau 8,83 persen dan di daerah perdesaan sebanyak 58031 jiwa atau 91,17 persen. Persentase distribusi penduduk menurut kecamatan bervariasi dari yang terendah sebesar 15,52 persen di Kecamatan Modayag Barat hingga yang tertinggi sebesar 29,24 persen di Kecamatan Modayag.
Penduduk laki-laki Kabupaten Bolaang Mongondow Timur sebanyak 33299 jiwa dan perempuan sebanyak 30355 jiwa. Seks rasio penduduk Kabupaten Bolaang Mongondow Timur adalah 110 , berarti terdapat 110 laki-laki untuk setiap 100 perempuan. Seks rasio menurut kecamatan yang terendah adalah Kecamatan Modayag sebesar 107 dan tertinggi adalah Kecamatan Kotabunan sebesar 115.

Median umur penduduk Kabupaten Bolaang Mongondow Timur tahun 2010 adalah 28,06 tahun. Angka ini menunjukkan bahwa penduduk Kabupaten Bolaang Mongondow Timur termasuk kategori menengah. Penduduk suatu wilayah dikategorikan penduduk muda bila median umur $<20$, penduduk menengah jika median umur 20-30, dan penduduk tua jika median umur > 30 tahun. Rasio ketergantungan penduduk Kabupaten Bolaang Mongondow Timur adalah 51,20. Angka ini menunjukkan bahwa setiap 100 orang usia produktif (15-64 tahun) akan menanggung sekitar 51 orang usia tidak produkif (0-14 dan 65+), yang menunjukkan banyaknya beban tanggungan penduduk suatu wilayah. Rasio ketergantungan di daerah perkotaan adalah 55,59 sementara di daerah perdesaan 50,79.

Jumlah penduduk yang aktif secara ekonomi (angkatan kerja) di Kabupaten Bolaang Mongondow Timur berdasarkan hasil Sensus Penduduk 2010 (SP2010) adalah 25,987 orang, yang terdiri dari 20,140 laki-laki dan 5,847 perempuan. Dari jumlah tersebut, jumlah yang bekerja adalah 25,148 orang dan pencari kerja sebesar 839 orang. Dengan jumlah penduduk 15 tahun ke atas sebanyak 44,924 jiwa, tingkat partisipasi angkatan kerja (TPAK) di Kabupaten Bolaang Mongondow Timur adalah 57,85 persen, dimana TPAK laki-laki adalah 85,30 persen dan TPAK perempuan sebesar 27,44 persen. Tingkat pengangguran terbuka (TPT) yang menggambarkan persentase penganggur terhadap total angkatan kerja adalah 3,23 persen, dimana TPT laki-laki adalah 0,9 persen, sedangkan TPT perempuan adalah 11,3 persen.

\section{Keadaan Perekonomian \\ Kabupaten Bolaang Mongondow Timur}

Keadaan perekonomian Kabupaten

Bolaang Mongondow Timur secara keseluruhan tercermin dari PDRB. Secara konsepsi, PDRB menggambarkan seberapa 
besar proses kegiatan ekonomi (tingkat produktivitas ekonomi ) di suatu wilayah. Apa bila suatu sektor ekonomi mempunyai kontribusi kecil dan pertumbuhan melambat, maka hal tersebut akan menghambat laju pertumbuhan ekonomi secara keseluruhan. Oleh karena itu, PDRB merupakan gambaran nyata hasil aktivitas pelaku ekonomi dalam memproduksi barang dan jasa yang dihitung sebagai akumulasi dari pencapaian nilai transaksi dari berbagai sektor ekonomi dalam kehidupan masyarakat.

Tingkat pertumbuhan secara keseluruhan merupakan rata-rata tertimbang dari tingkat pertumbuhan sektoralnya. Semakin besar peranan sektoral dalam struktur ekonomi, maka semakin besar pula kontribusinya terhadap tingkat pertumbuhan ekonomi. Jika suatu sektor mempunyai peran yang dominan tetapi tingkat pertumbuhannya rendah, maka akan menghambat tingkat pertumbuhan secara keseluruhan. Jika sektor tersebut mempunyai tingkat pertumbuhan yang tinggi, maka otomatis akan menyebabkan tingkat pertumbuhan ekonomi yang tinggi pula.

Pertumbuhan ekonomi menunjukkan adanya perubahan tingkat kegiatan ekonomi yang terjadi di suatu daerah dari tahun ke tahun yang disebabkan oleh dua faktor yaitu perubahan tingkat kegiatan ekonomi dan perubahan harga. Perhitungan pertumbuhan ekonomi mengalami perubahan tahun dasar, yang sebelumnya dihitung menggunakan tahun dasar 2000 dan Klasifikasi Lapangan Usaha (KLUI) 1990, sekarang telah menggunakan tahun dasar 2010 dan klasifikasi baku lapangan usaha (KBLUI) 2009.

\section{Analisis Data}

\section{Analisis Location Quotient (LQ)}

Teori dasar dari model basis ekonomi berpandangan bahwa determinan pertumbuhan ekonomi suatu daerah berhubungan secara langsung dengan permintaan permintaan dari daerah lain, sehingga dengan adanya permintaan terhadap barang dan jasa merangsang pertumbuhan industri atau sektor lain yang memanfaatkan sumber daya lokal, baik berupa tenaga kerja maupun material, yang pada gilirannya akan membangkitkan perekonomian daerah tersebut. Untuk melakukan analisis basis ekonomi salah satu metode yang digunakan adalah Analisis Location Quotient (LQ) yang bertujuan untuk mengetahui dan menentukan sektor ekonomi yang merupakan sektor basis dan non basis. Sektor basis merupakan sektor dengan kegiatan ekonomi yang hasil produksinya dapat melayani pasar baik di dalam maupun di luar batas perekonomian masyarakat yang bersangkutan. Sedangkan sektor non basis merupakan sektor dengan kegiatan ekonomi yang hanya mampu menyediakan barang dan jasa yang dibutuhkan oleh masyarakat yang bertempat tinggal di dalam batas perekonomian masyarakat. Bertambah banyaknya kegiatan basis dalam suatu daerah akan menambah arus pendapatan ke dalam daerah yang bersangkutan, menambah permintaan barang dan jasa sehingga akan menimbulkan kenaikan volume kegiatan. Sebaliknya berkurangnya kegiatan basis akan mengurangi pendapatan suatu daerah dan turunnya permintaan terhadap barang dan jasa sehingga akan menurunkan volume kegiatan. Dalam proses perhitungannya analisis LQ menggunakan perbandingan antara kondisi perekonomian suatu wilayah dengan perekonomian acuan yang mlingkupi daerah yang lebih luas, dalam penelitian ini membandingkan antara perekonomian Kabupaten Bolaangmongondow Timur dengan kondisi perekonomian Provinsi Sulawesi Utars sebagai daerah acuan. Apabila hasil perhitungan menunjukkan angka lebih dari satu (LQ > 1) berarti sektor atau sub sektor tersebut merupakan sektor basis. Sebaliknya apabila hasilnya menunjukkan angka kurang dari satu $(\mathrm{LQ}<1)$ berarti sektor atau sub sektor tersebut merupakan sektor non basis. Hasil perhitungan LQ Kabupaten Bolaangmongondow Timur dengan menggunakan PDRB sebagai berikut:

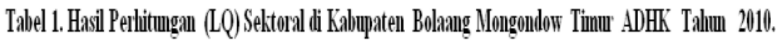

\begin{tabular}{|c|c|c|c|c|c|c|}
\hline \multirow[t]{2}{*}{ SEKTOR } & \multicolumn{5}{|c|}{ Location Quotient (LQ) } & \multirow[t]{2}{*}{ basis non basis } \\
\hline & 2011 & 2012 & 2013 & 2014 & 2015 & \\
\hline Pertanian, Kehutanan, dan Perikanan & 0.35 & 0.36 & 0.34 & 0.34 & 0.33 & non basis \\
\hline Pertambangand dan Penggalian & 0.60 & 0.61 & 0.57 & 0.56 & 0.54 & non basis \\
\hline Industri Pengolahan & 0.36 & 0.38 & 0.36 & 0.35 & 0.35 & non basis \\
\hline Pengadaan Listrilidan Gas & 1.63 & 1.77 & 1.83 & 2.00 & 2.13 & Basis \\
\hline Konstruksi & 0.80 & 1.84 & 1.57 & 1.39 & 1.31 & Basis \\
\hline Perdagangan Besar dan Eceran;: Reparasi Mobil dan Sepeda Motor & 1.05 & 0.90 & 0.92 & 0.91 & 0.96 & non basis \\
\hline Informasi dan Komunikasi & 1.65 & 1.10 & 1.04 & 1.03 & 1.03 & Basis \\
\hline Jasa Keuangan dan Asuransi & 2.40 & 0.10 & 0.98 & 1.03 & 0.92 & non basis \\
\hline Jasa lainnya & 0.67 & 1.19 & 1.13 & 1.09 & 1.09 & basis \\
\hline
\end{tabular}

Sumber: BPS Kota Kotamobagu, 2016 (diolah) 
Tabel 1 menunjukkan bahwa berdasarkan analisis location quotient (LQ), bahwa dari seluruh sektor yang ada di kabupaten Bolaang Mongondow Timur hanya sektor Pengadaan Listrik dan Gas, Konstruksi, Informasi dan Komunikasi, dan Jasa lain yang memiliki nilai LQ $>1$. Hal tersebut menandakan bahwa sektorsektor ini merupakan sektor basis di kabupaten Bolaang Mongondow Timur. Sedangkan yang merupakan sektor non basis adalah Pertanian, Kehutanan, dan Perikanan, Pertambangan dan Penggalian, Industri Pengolahan, Konstruksi, Perdagangan Besar dan Eceran; Reparasi Mobil dan Sepeda Motor, dan Jasa Keuangan dan Asuransi. Yang artinya sektor tersebut memiliki nilai $L Q<1$.

\section{Kontribusi Sektor basis Terhadap PDRB Kabupaten Bolaang Mongondow Timur Periode 2011-2015.}

Sektor basis mendominasi perekonomian di kabupaten Bolaang Mongondow Timur dalam peranannya dibanding sektor-sektor lainnya. Peran sektor basis terhadap besarnya PDRB di Kabupaten Bolaang Mongondow Timur dapat di hitung dengan menggunakan rumus proporsi yaitu dengan cara membandingkan besarnya masingmasing nilai tambah dengan PDRB dikalikan $100 \%$. Hasil perhitungan kontribusi melalui metode proporsi dapat dilihat pada Tabel 2 sampai Tabel 6 di bawah ini.

\begin{tabular}{cccc} 
Tabel 2. & $\begin{array}{c}\text { Kontribusi } \\
\text { Terhadap PDRB } \\
\text { Timur Tahun 2011-2015. }\end{array}$ & $\begin{array}{c}\text { Pengadaan } \\
\text { Kabupaten Bolaang }\end{array}$ & Mongondow \\
& $\begin{array}{c}\text { PDRB Total } \\
\text { Tahun }\end{array}$ & $\begin{array}{c}\text { PDRB Sektor Pengadaan } \\
\text { Listrik dan Gas }\end{array}$ & Konstribusi (\%) \\
& (Juta Rupiah) & $3,024.20$ & $0.37 \%$ \\
\hline 2011 & $813,186.30$ & $3,349.70$ & $0.38 \%$ \\
2012 & $871,541.60$ & $3,774.00$ & $0.40 \%$ \\
2013 & $950,171.80$ & $4,185.10$ & $0.42 \%$ \\
2014 & $1,008,393.30$ & $4,517.70$ & $0.42 \%$ \\
2015 & $1,068,860.80$ & $3,770.14$ & $0.40 \%$ \\
\hline Rata-rata & $942,430.76$ & & \\
\hline
\end{tabular}

Sumber: BPS Kota Kotamobagu, 2016 (diolah)

Tabel 2 menunjukkan bahwa perhitungan melalui metode proporsi kontribusi sektor basis terhadap Produk Domestik Regional Bruto (PDRB) Kabupaten Bolaang Mongondow Timur dari hasil analisis menggambarkan bahwa kontribusi sektor basis yakni sektor Pengadaan Listrik dan Gas dari tahun ke tahun terus mengalami peningkatan. Sektor Pengadaan Listrik dan Gas memiliki nilai kontribusi tertinggi berada pada tahun 2015 sebesar $0.42 \%$, dan terus meningkat dari tahun sebelumnya, secara rata-rata kontribusi sektor Pengadaan Listrik dan Gas terhadap Produk Domestik Regional Bruto (PDRB) Kabupaten Bolaang Mongondow Timur adalah sebesar $0,40 \%$, per tahun selama periode tahun 20112015.

\begin{tabular}{cccc} 
Tabel 3. & \multicolumn{3}{c}{$\begin{array}{c}\text { Kontribusi Sektor Konstruksi Terhadap PDRB } \\
\text { Bolaang Mongondow Timur Tahun 2011-2015. }\end{array}$} \\
\hline Tahun & $\begin{array}{c}\text { PDRB Total } \\
\text { (Juta Rupiah) }\end{array}$ & $\begin{array}{c}\text { PDRB Sektor } \\
\text { Konstruksi }\end{array}$ & Konstribusi (\%) \\
\hline 2011 & $813.186,30$ & $163.088,90$ & $20,06 \%$ \\
2012 & $871.541,60$ & $181.524,50$ & $20,83 \%$ \\
2013 & $950.171,80$ & $212.842,30$ & $22,40 \%$ \\
2014 & $1.008 .393,30$ & $231.320,60$ & $22,94 \%$ \\
2015 & $1.068 .860,80$ & $258.421,90$ & $24,18 \%$ \\
\hline Rata-rata & $942.430,76$ & $209.439,64$ & $22,22 \%$ \\
\hline
\end{tabular}

Sumber: BPS Kota Kotamobagu, 2016 (diolah)

Tabel 3 menunjukkan bahwa perhitungan melalui metode proporsi kontribusi sektor basis terhadap Produk Domestik Regional Bruto (PDRB) Kabupaten Bolaang Mongondow Timur dari hasil analisis menggambarkan bahwa kontribusi sektor basis yakni sektor Konstruksi dari tahun ke tahun terus mengalami peningkatan. Sektor Konstruksi memiliki nilai kontribusi tertinggi berada pada tahun 2015 sebesar $24,18 \%$, dan terus meningkat dari tahun sebelumnya, secara rata-rata kontribusi sektor Konstruksi terhadap Produk Domestik Regional Bruto (PDRB) Kabupaten Bolaang Mongondow Timur adalah sebesar 22,22\%, per tahun selama periode tahun 2011-2015.

\begin{tabular}{|c|c|c|c|}
\hline Tabel 4. & $\begin{array}{l}\text { Kontribusi S } \\
\text { Reparasi Mo } \\
\text { PDRB Kabı } \\
\text { Tahun 2011-2 }\end{array}$ & $\begin{array}{l}\text { xtor Perdagangan Besa } \\
\text { il dan Sepeda Mot } \\
\text { baten Bolaang Mong } \\
\text { 15. }\end{array}$ & $\begin{array}{l}\text { dan Eceran; } \\
\text { or Terhadap } \\
\text { ndow Timur }\end{array}$ \\
\hline Tahun & $\begin{array}{l}\text { PDRB Total } \\
\text { (Juta Rupiah) }\end{array}$ & $\begin{array}{c}\text { PDRB Sektor } \\
\text { Perdagangan Besar dan } \\
\text { Eceran; Reparasi Mobil } \\
\text { dan Sepeda Motor }\end{array}$ & Konstribusi (\% \\
\hline 2011 & $813.186,30$ & $211.854,50$ & $26,05 \%$ \\
\hline 2012 & $871.541,60$ & $222.366,20$ & $25,51 \%$ \\
\hline 2013 & $950.171,80$ & $240.920,90$ & $25,36 \%$ \\
\hline 2014 & $1.008 .393,30$ & $260.899,20$ & $25,87 \%$ \\
\hline 2015 & $1.068 .860,80$ & $275.788,60$ & $25,80 \%$ \\
\hline Rata-rata & $942.430,76$ & $242.365,88$ & $25,72 \%$ \\
\hline
\end{tabular}

Sumber: BPS Kota Kotamobagu, 2016 (diolah)

Tabel 4 menunjukkan bahwa perhitungan melalui metode proporsi kontribusi sektor basis terhadap Produk Domestik Regional Bruto (PDRB) Kabupaten Kabupaten Bolaang Mongondow Timur dari 
hasil analisis menggambarkan bahwa kontribusi sektor basis yakni sektor Perdagangan Besar dan Eceran; Reparasi Mobil dan Sepeda Motor dari tahun ke tahun terus mengalami perubahan. Sektor Perdagangan Besar dan Eceran; Reparasi Mobil dan Sepeda Motor memiliki nilai kontribusi tertinggi berada pada tahun 2011 sebesar $26,05 \%$, dan terus terjadi perubahan sehingga kontribusi pada tahun 2015 dengan nilai sebesar $25,80 \%$, menurun dari tahun sebelumnya sebesar $25,87 \%$ pada tahun 2014 , dan secara rata-rata kontribusi Sektor Perdagangan Besar dan Eceran; Reparasi Mobil terhadap Produk Domestik Regional Bruto (PDRB) Kabupaten Kabupaten Bolaang Mongondow Timur adalah sebesar 25,72\%, per tahun selama periode tahun 2011-2015.

\begin{tabular}{|c|c|c|c|}
\hline Tabel 5 & $\begin{array}{l}\text { Kontribusi } \\
\text { Terhadap } \\
\text { Mongondow }\end{array}$ & $\begin{array}{c}\text { Sektor Informasi dan } \\
\text { PDRB Kabupaten } \\
\text { Timur Tahun 2011-2015 }\end{array}$ & $\begin{array}{r}\text { Komunikasi } \\
\text { Bolaang } \\
\end{array}$ \\
\hline Tahun & $\begin{array}{l}\text { PDRB Total } \\
\text { (Juta Rupiah) }\end{array}$ & $\begin{array}{l}\text { PDRB Sektor } \\
\text { Informasi dan } \\
\text { Komunikasi }\end{array}$ & Konstribusi (\%) \\
\hline 2011 & $813.186,30$ & $32.324,90$ & $3,98 \%$ \\
\hline 2012 & $871.541,60$ & $35.721,30$ & $4,10 \%$ \\
\hline 2013 & $950.171,80$ & $39.285,20$ & $4,13 \%$ \\
\hline 2014 & $1.008 .393,30$ & $43.400,60$ & $4,30 \%$ \\
\hline 2015 & $1.068 .860,80$ & $47.411,20$ & $4,44 \%$ \\
\hline Rata-rata & $942.430,76$ & $39.628,64$ & $4,20 \%$ \\
\hline
\end{tabular}

Tabel 5 menunjukkan bahwa perhitungan melalui metode proporsi kontribusi sektor basis terhadap Produk Domestik Regional Bruto (PDRB) Kabupaten Bolaang Mongondow Timur dari hasil analisis menggambarkan bahwa kontribusi sektor basis yakni sektor Informasi dan Komunikasi dari tahun ke tahun terus mengalami peningkatan yang signifikan. sektor informasi dan komunikasi memiliki nilai kontribusi dengan nilai rata-rata $4,20 \%$, per tahun selama periode tahun 2011-2015.

Tabel 6. Kontribusi Sektor Jasa Keuangan dan Asuransi Terhadap PDRB Kabupaten Bolaang Mongondow Timur Tahun 2011-2015.

\begin{tabular}{lrcc}
\hline Tahun & $\begin{array}{r}\text { PDRB Total } \\
\text { (Juta Rupiah) }\end{array}$ & $\begin{array}{c}\text { PDRB Sektor Jasa } \\
\text { Keuangan dan Asuransi }\end{array}$ & Konstribusi (\%) \\
\hline 2011 & $813.186,30$ & $139.022,80$ & $17,10 \%$ \\
2012 & $871.541,60$ & $150.333,10$ & $17,25 \%$ \\
2013 & $950.171,80$ & $159.239,20$ & $16,76 \%$ \\
2014 & $1.008 .393,30$ & $162.623,30$ & $16,13 \%$ \\
2015 & $1.068 .860,80$ & $166.646,70$ & $15,59 \%$ \\
\hline Rata- & $\mathbf{9 4 2 . 4 3 0 , 7 6}$ & $\mathbf{1 5 5 . 5 7 3 , 0 2}$ & $\mathbf{1 6 , 5 1 \%}$ \\
rata & $\mathbf{4}$ &
\end{tabular}

Tabel 6 menunjukkan bahwa perhitungan melalui metode proporsi kontribusi sektor basis terhadap Produk Domestik Regional Bruto (PDRB) Kabupaten Bolaang Mongondow Timur dari hasil analisis menggambarkan bahwa kontribusi sektor basis yakni sektor Jasa Keuangan dan Asuransi dari tahun ke tahun mengalami penurunan dimana pada tahun 2011 memberikan kontribusi sebesar $17,10 \%$, dan mengalami penurunan pada tahun berikutnya sehingga di tahun 2015 hanya memberikan kontribusi sebesar $15,59 \%$. Dengan rata-rata kontribusi pertahunnya sebesar $16,51 \%$, selama periode 2011-2015.

Sektor basis memiliki peran penting bagi perekonomian Kabupaten Bolaang Mongondow Timur. Hasil analisis data menunjukkan sektorsektor yang menjadi sektor basis berdasarkan hasil perhitungan LQ tahun 2011-2015 di kabupaten Bolaang Mongondow Timur terdapat lima sektor, yaitu Pengadaan Listrik dan Gas, Konstruksi, Perdagangan Besar dan Eceran; Reparasi Mobil dan Sepeda Motor, Informasi dan Komunikasi, Jasa Keuangan dan Asuransi. Terjadinya arus pendapatan dari luar daerah ini akan menyebabkan kenaikan konsumsi dan investasi dan pada gilirannya akan menaikkan pendapatan dan menciptakan kesempatan kerja yang baru.

\section{Analisis Dynamic Location Quotient (DLQ)}

Dalam analisis basis ekonomi ini juga gunakan metode Dinamic Location Quotient (DLQ). Prinsip DLQ sebenarnya masih sama sama dengan LQ, hanya untuk mengintroduksikanlaju pertumbuhan digunakan asumsi bahwa nilai tambah sektoral maupun PDRB mempunyai rata-rata laju pertumbuhan sendiri-sendiri selama kurun waktu antara tahun (0) dan tahun (t). Tafsiran atas DLQ sebenarnya masih sama dengan LQ, kecuali perbandingan ini lebih menekankan pada laju pertumbuhan. Jika DLQ $=1$, berarti laju pertumbuhan sektor $\mathrm{i}$ terhadap laju pertumbuhan PDRB daerah Kabupaten BOLTIM sebanding dengan laju pertumbuhan sektor tersebut pada PDRB Provinsi Sulawesi Utara. Jika DLQ $<1$, artinya proporsi laju pertumbuhan sektor i terhadap laju pertumbuhan PDRB daerah Kabupaten BOLTIM lebih rendah dibandingkan laju pertumbuhan sektor yang sama pada PDB Provinsi Sulawesi 
Utara. Sebaliknya, jika DLQ > 1, berarti proporsi laju pertumbuhan sektor i terhadap laju pertumbuhan PDRB daerah Kabupaten BOLTIM lebih cepat dibandingkan laju pertumbuhan sektor yang sama pada PDRB Provinsi Sulawesi Utara. Kalau keadaan tetap sebagaimana adanya saat ini, maka dapat diharapkan bahwa sektor ini unggul pada masa yang akan datang.

Berdasarkan data laju pertumbuhan ekonomi Kabupaten Bolaang Mongondow Timur dan Provinsi Sulawesi Utara dalam kurun waktu tahun 2011-2015, diperoleh hasil perhitungan DLQ sebagaimana pada Tabel 7 . Dapat diketahui bahwa terdapat dua sektor yang dapat menjadi sektor basis di masa yang akan datang dengan (DLQ > 1).

Tabel 7. Hasil Perhitungan DLQ Kabupaten Bolaang

\begin{tabular}{ll}
\multicolumn{1}{c}{ Mongondow Timur Tahun 2011-2015. } \\
\hline \multicolumn{1}{c}{ SEKTOR } & DLQ \\
\hline Pertanian, Kehutanan, dan Perikanan & 0,93 \\
Pertambangan dan Penggalian & 0,90 \\
Industri Pengolahan & 0,96 \\
Pengadaan Listrik dan Gas & 1,29 \\
Konstruksi & 1,15 \\
Perdagangan Besar dan Eceran; Reparasi Mobil dan Sepeda Motor & 0,97 \\
Informasi dan Komunikasi & 0,97 \\
Jasa Keuangan dan Asuransi & 0,79 \\
Jasa lainnya & 0,98 \\
\hline Sumber: BPS Kota Kotamobagu, 2016 (diolah)
\end{tabular}

Tabel 7 menunjukkan bahwa hanya terdapat dua sektor yang akan menjadi sektor basis di masa yang akan datang diantaranya sektor Pengadaan Listrik dan Gas serta sektor Konstruksi.

\section{Perbandingan LQ dan DLQ}

Analisi LQ dan DLQ digunakan untuk membandingkan kinerja setiap sektor saat ini maupun dimasa mendatang. Hasil perbandingan dapat dilihat pada Tabel 8 .

Tabel 8. Perubahan Posisi Sektor Berdasarkan Nilai LQ Dan DLQ Kabupaten

\begin{tabular}{llll}
$\begin{array}{l}\text { Tabel 8. Perubahan Posisi Sektor Berdasarkan Nilai LQ Dan DLQ Kabupaten } \\
\text { Bolaang Mongondow Timur. }\end{array}$ & & & \\
\hline \multicolumn{1}{c}{ SEKTOR } & LQ & DLQ & Keterangan \\
\hline Pertanian, Kehutanan, dan Perikanan & 0,33 & 0,93 & Nonbasis-Nonbasis \\
Pertambangan dan Penggalian & 0,54 & 0,90 & Nonbasis-Nonbasis \\
Industri Pengolahan & 0,35 & 0,96 & Nonbasis-Nonbasis \\
Pengadaan Listrik dan Gas & 2,13 & 1,29 & Basis-Basis \\
Konstruksi & 1,31 & 1,15 & Basis-Basis \\
Perdagangan Besar dan Eceran; Reparasi & 0,96 & 0,97 & Nonbasis-Nonbasis \\
Mobil dan Sepeda Motor & & & \\
Informasi dan Komunikasi & 1,03 & 0,97 & Basis-Nonbasis \\
Jasa Keuangan dan Asuransi & 0,92 & 0,79 & Nonbasis-Nonbasis \\
Jasa lainnya & 1,09 & 0,98 & Basis-Nonbasis \\
\hline Sumber: BPS Kota Kotamobagu, 2016 (diolah) & & &
\end{tabular}

Tabel 8 menunjukkan bahwa sektor pertanian dengan nilai LQ 0,33 yang awalnya merupakan sektor non basis, Masih tetap menjadi sektor non basis dengan nilai DLQ 0,93, sektor Pertambangan Dan Penggalian yang awalnya merupakan sektor non basis dengan nilai LQ 0,54 masih tetap menjadi non basis dengan nilai DLQ 0,90, sektor industri pengolahan masih tetap non basi dengan nilai DLQ 0,96, sektor Pengadaan Listrik Dan Gas tetap pada posisi dengan nilai LQ 2,29 dan mengalami penurunana dengan nilai DLQ 1,29, sektor Konstruksi tetap pada posisi basis dengan nilai DLQ 1,15, sektor Perdagangan Besar dan Eceran; Reparasi Mobil dan Sepeda Motor tetap pada pada posisi sektor non basis dengan nilai DLQ 0,97, sektor Informasi Dan Komunikasi yang awalnya merupakan sektor basis dengan nilai LQ 1,03 menjadi sector non basis dengan nilai DLQ 0,97, sektor Jasa Keuangan Dan Asuransi tetap pada posisi dengan nilai DLQ 0,79, dan sektor Jasa Lainnya yang awalnya merupakan sector basis dengan nilai LQ 1,09 menjadi sector non basis di massa yang akan datang dengan nilai DLQ 0,98.

\section{KESIMPULAN DAN SARAN}

\section{Kesimpulan}

1. Berdasarkan analisis LQ sektor yang menjadi sektor basis yaitu sektor Pengadaan Listrik dan Gas, Konstruksi, Informasi dan Komunikasi, dan Jasa lainnya.

2. Berdasarkan analisis DLQ sektor yang menjadi sektor basis pada masa yang akan datang yaitu sektor pengadaan listrik dan gas, dan sektor konstruksi.

\section{Saran}

Pemerintah daerah Kabupaten Bolaang Mongondow Timur berupaya menjaga kinerja sektor uggulan serta lebih memperhatikan sektor pertanian yang menjadi tumpuan mata pencaharian sebagian besar masyarakat kabupaten Bolaang Mongondow Timur, sehingga terus tumbuh dan berkembang dalam memenuhi kebutuhan daerah sendiri maupun mengekspor ke daerah lain sehingga menjadi peranan penting terhadap perekonomian di kabupaten Bolaang Mongondow Timur. 


\section{DAFTAR PUSTAKA}

Anonimous. Badan Pusat Statistik. Provinsi Sulawesi Utara. 2016. Produk Domestik Regional Bruto Menurut Lapangan Usaha 2011-2015.

Anonimous. Badan Pusat Statistik. Kota Kotamobagu. 2016. Produk Domestik Regional Bruto. Menurut Lapangan Usaha 2011-2015.
Anonimous. Badan Pusat Statistik Kota Kotamobagu.2016. Bolaang Mongondow Dalam Angka 2015.

Sadono, Sukirno. Ekonomi Pembangunan Proses, Masalah dan Dasar Kebijakan: Perubahan Struktur Ekonomi dalam Proses Pembangunan, Kencana, Jakarta,2007. 